\title{
PENGARUH PROSEDUR BANK, LOKASI BANK DAN PERSEPSI NASABAH TENTANG BANK SYARIAH TERHADAP MINAT NASABAH DALAM MENGAJUKAN PEMBIAYAAN MUR ĀBAHAH PADA BPRS BUMI ARTHA SAMPANG KC KEBUMEN
}

\author{
Hajar Mukaromah', Miftahur Rahman², Aqli Qorib Alfarisy ${ }^{3}$ \\ ${ }^{1,2,3}$ Sekolah Tinggi Agama Islam An-Nawawi Purworejo \\ ${ }^{1}$ hajarmukaromah90@gmail.com, ${ }^{2}$ miftah131@gmail.com, \\ 3aqlialfarisy45@gmail.com
}

\begin{abstract}
Abstrak: Di daerah Kebumen ada BPRS Bumi Artha Sampang yang banyak diminati masyarakat, letaknya pun sangat strategis dan mayoritas masyarakat Kebumen beragama Islam. Oleh karena itu rumusan masalah pada pembahasan kali ini adalah seberapa besar pengaruh prosedur bank, lokasi bank dan persepsi secara parsial atau sendiri sendiri terhadap minat nasabah melakukan pembiayaan murābahah pada BPRS Bumi Artha KC Kebumen dan seberapa besar pengaruh prosedur bank, lokasi bank dan persepsi secara simultan atau bersama sama terhadap minat nasabah melakukan pembiayaan murābahah pada BPRS Bumi Artha KC Kebumen? Penelitian ini menggunakan jenis penelitian kuantitatif dan sumber data primer. Sampel dalam penelitian ini menggunakan accidental sampling. Teknik pengumpulan data menggunakan metode kuisioner yaitu pengumpulan data berupa pertanyaan tertulis untuk memperoleh keterangan dari sejumlah responden. Metode analisis datanya menggunakan metode regresi berganda, uji asumsi klasik dan uji hipotesis (uji t dan uji $F$ ), pengolahan datanya menggunakan SPSS versi 25. Uji parsial (uji t) menunjukkan masing masing variabel diperoleh hasil bahwa semua variabel yang diteliti memiliki pengaruh terhadap minat nasabah mengajukan pembiayaan murābahah pada BPRS Bumi Artha Sampang KC Kebumen. Sedangkan antara variabel prosedur bank, lokasi bank dan persepsi berpengaruh secara simultan atau bersama (uji F) sama terhadap minat nasabah mengajukan pembiayaan murābahah pada BPRS Bumi Artha Sampang KC Kebumen. Sebesar 0,490 atau 49\%. Dan sisanya yaitu 51\% dipengaruhi oleh faktor lain yang tidak diteliti dalam penelitian ini.
\end{abstract}

Kata kunci: Prosedur, Lokasi, Persepsi dan Minat

Abstract: In the area of Kebumen, there is BPRS Bumi Artha Sampang which is in great demand by the public, its location is very strategic and the majority of Kebumen people are Muslims. Therefore, the formulation of the problem in this discussion is how much influence the bank procedure, bank location and perception partially or alone on the customer's interest in doing murābahah financing at BPRS 
Bumi Artha KC Kebumen and how much influence is the bank procedure, bank location and perception simultaneously or together on customer interest in doing murābahah financing at BPRS Bumi Artha KC Kebumen? This research uses quantitative research and primary data sources. The sample in this study used accidental sampling. The data collection technique uses a questionnaire method, namely data collection in the form of written questions to obtain information from a number of respondents. Methods of data analysis using multiple regression methods, classic assumption tests and hypothesis testing ( $t$ test and $F$ test), data processing using SPSS version 25. The partial test ( $t$ test) shows that each variable shows that all the variables studied have an influence on customer interest in proposing murābahah financing at BPRS Bumi Artha Sampang KC Kebumen. Meanwhile, bank procedure, bank location and perception variables have the same effect or jointly ( $F$ test) on customers' interest in proposing murābahah financing at BPRS Bumi Artha Sampang KC Kebumen. In the amount of 0.490 or $49 \%$. And the remaining $51 \%$ is influenced by other factors not examined in this study.

Keywords:Procedures, Location, Perceptions and Interests

\section{PENDAHULUAN}

Pembiayaan murābahah masih mendominasi pembiayaan di bank syariah. Murābahah bi tsamān aj̄̄l atau lebih dikenal sebagai murābahah berasal dari kata ribhu (keuntungan) adalah transaksi jual beli dimana bank menyebut jumlah keuntungannya. Bank bertindak sebagai penjual, sementara nasabah sebagai pembeli. Murābahah dapat diartikan sebagai akad jual beli barang dengan harga jual sebesar biaya perolehan ditambah keuntungan yang disepakati dan penjual harus mengungkapkan biaya perolehan barang tersebut kepada pembeli. ${ }^{1}$

Murābahah dalam fikih Islam yang berarti "suatu bentuk jual beli tertentu ketika penjual menyatakan biaya perolehan barang, meliputi harga barang dan biaya-biaya lain yang dikeluarkan untuk memperoleh barang tersebut, dan tingkat keuntungan (margin) yang diinginkan. Pembiayaan murābahah dalam istilah teknis perbankan diartikan sebagai "suatu pembiayaan dengan suatu perjanjian yang disepakati antara bank Syariah dengan nasabah, dimana bank menyediakan pembiayaan untuk pembelian bahan baku atau modal kerja lainnya yang dibutuhkan

\footnotetext{
${ }^{1}$ Karnaen A. Permana dan Muhammad Syafi'i Antonio, Apa dan Bagaimana Bank Islam cet. III, (Solo: Amanah Bunda Sejahtera, 1999), h. 27.
} 
nasabah yang akan dibayar kembali oleh nasabah sebesar harga jual bank (harga beli bank ditambah margin keuntungan) pada waktu yang ditetapkan". ${ }^{2}$

Muḍārabah atau penanaman modal adalah penyerahan modal uang kepada orang yang berniaga sehingga ia mendapatkan presentase keuntungan. Sebagai bentuk kontrak, Muḍarabah merupakan akad bagi hasil ketika pemilik modal menyediakan modal kepada pengusaha sebagai pengelola untuk melakukan usaha produktif dengan syarat bahwa keuntungan yang dihasilkan akan dibagi diantara mereka menurut kesepakatan. ${ }^{3}$

Pada penelitian kali ini penulis hanya akan mengulas tentang seberapa besar pengaruh dari prosedur yang ditawarkan kepada nasabah. Tahap awal proses pembiayaan adalah permohonan pembiayaan secara formal, permohonan pembiayaan dilakukan secara tertulis dari nasabah kepada officer bank. Namun dalam implementasinya, permohonan dapat dilakukan secara lisan terlebih dahulu dan dilanjutkan dengan permohonan tertulis jika menurut officer bank usaha tersebut layak untuk dibiayai. ${ }^{4}$

Selain prosedur, lokasi juga memiliki peranan penting terhadap sumbangsih bertambahnya nasabah di suatu bank. . Pemilihan lokasi yang baik merupakan keputusan yang sangat penting. Keputusan lokasi mempunyai dampak yang permanen dan jangka panjang, lokasi akan mempengaruhi pertumbuhan usaha dimasa mendatang. Lokasi yang dipilih haruslah mampu mengalami pertumbuhan ekonomi sehingga usahanya dapat bertahan, apabila nilai lokasi memburuk akibat perubahan lingkungan yang dapat terjadi setiap waktu, mungkin saja usaha tersebut harus dipindahkan atau ditutup. Lokasi adalah tempat dimana suatu usaha atau aktivitas usaha dilakukan. ${ }^{5}$

Persepsi adalah tanggapan (penerimaan) langsung dari sesuatu, serapan, perlu diteliti, proses seseorang mengetahui beberapa hal melalui panca indranya. Persepsi

\footnotetext{
${ }^{2}$ Muhajir, Fathudin, Hary Listyadi. (2021). Penyelesaian Pembiayaan Murābahah Bermasalah Di BMT Mikat Al-Khidmah Purworejo. Al-Mubin; Islamic Scientific Journal. 10-23.

${ }^{3}$ Muhajir, Dina Hady Chaeruddin. (2021). Implementasi Akad Pembiayaan Mudharabah di BMT AnNawawi Cabang Pituruh Perspektif Hukum Ekonomi Syariah. At-Tasyri'iy Jurnal Prodi Perbankan Syariah. 117.

${ }^{4}$ Muhammad Syafi'i Antonio, Bank Syariah: Dari Teori Ke Praktik, h. 171.

${ }^{5}$ Kasmir, Marketing dan Kasus Kasus Pilihan, (Jakarta: Center For Academic Publishing Service, 2006), h. 129.
} 
sebagai proses yang digunakan oleh individu untuk memilih, mengorganisasi dan menginterpretasi masukan informasi guna menciptakan gambaran dunia yang memiliki arti. ${ }^{6}$

Persepsi masyarakat terhadap bank syariah merupakan hal penting yang harus diperhatikan dalam rangka mengukur, merencanakan dan menerapkan strategi pengembangan Bank syariah di bidang apapun.

Pada BPRS Bumi Artha Sampang KC Kebumen terdapat beberapa produk pembiayaan yaitu murābahah, mudhōrābah, musyārokah. Dari sekian banyak produk pembiayaan yang paling banyak diminati adalah murābahah. Maka dari itu penulis tertarik dengan mengambil akad murābahah.

\section{KAJIAN TEORI DAN PENGEMBANGAN HIPOTESIS}

1. Minat

Minat adalah sikap jiwa seseorang termasuk ketiga fungsi jiwanya (kognisi, konasi, emosi), yang tertuju pada sesuatu, dari dalam hubungan itu unsur perasaan yang kuat. ${ }^{7}$

Minat sebagai aspek kejiwaan bukan hanya mewarnai perilaku seseorang untuk melakukan aktivitas yang menyebabkan seseorang merasa tertarik kepada sesuatu. Sedangkan nasabah merupakan konsumen sebagai penyedia dana dalam proses transaksi barang ataupun jasa. Dengan demikian pengertian minat nasabah yaitu: Pengaruh eksternal, kesadaran akan kebutuhan, pengenalan produk dan evaluasi alternatif adalah hal yang dapat menimbulkan minat beli konsumen. Pengaruh eksternal ini terdiri dari usaha pemasaran dan faktor sosial budaya. ${ }^{8}$

2. Prosedur

Prosedur adalah suatu urutan urutan kerani (clerical), biasanya melibatkan beberapa orang dalam suatu bagan atau lebih, disusun untuk menjamin adanya perlakuan yang seragam terhadap transaksi transaksi perusahaan yang sering terjadi. ${ }^{9}$

${ }^{6}$ Philip Kotler, Manajemen Pemasaran Edisi 12 (Indonesia: PT Macanan Jaya Cemerlang, 2009), h. 228.

${ }^{7}$ Abu Ahmadi, Psikologi Umum, (Jakarta: Rieneka Cipta, 1998), hlm. 151.

${ }^{8}$ Husein Umar, Metode Riset Bisnis, (Jakarta: PT. Gramedia Pustaka Utama, 2003), h. 102.

${ }^{9}$ Zaki Baridwan, Sistem Akuntansi, Penyusunan Prosedur dan Metode, (Yogyakarta, BPFE, 1992). h.3. 


\section{Lokasi}

Lokasi adalah suatu ruang di mana berbagai kegiatan yang dilakukan perusahaan untuk membuat produk yang diperoleh dan tersedia bagi pelanggan sasaran. Lokasi yang mudah dijangkau oleh pembeli dan dekat dengan pusat keramaian merupakan lokasi yang tepat untuk suatu usaha. Lokasi yang strategis bagi nasabah akan memperkecil pengorbanan energi dan waktu. ${ }^{10}$

Lokasi Bank adalah tempat pemasaran atau tempat tersedianya produk cabang bank dan pusat pengendalian perbankan. Dalam praktiknya ada beberapa macam lokasi kantor bank, yaitu lokasi kantor pusat, cabang utama, cabang pembantu, kantor kas, dan lokasi mesin-mesin Anjungan Tunai Mandiri (ATM). ${ }^{11}$

Keputusan lokasi seringkali melibatkan serangkaian faktor yang dapat berpengaruh terhadap pendapatan, biaya atau keduanya karna dapat berpengaruh terhadap laba. Faktor lain yang pengaruhnya terhadap laba tidak mudah untuk diukur adalah pertimbangan pemilihan lokasi. Lokasi merupakan saluran distribusi yaitu jalur yang dipakai untuk berpindah produk dari produsen ke konsumen. Lokasi adalah keputusan yang dibuat perusahaan berkaitan dengan dimana operasi dan stafnya akan ditempatkan. ${ }^{12}$

\section{Persepsi}

Persepsi merupakan salah satu aspek psikologis yang penting bagi manusia dalam merespon kehadiran berbagai aspek dan gejala di sekitarnya. Persepsi merupakan suatu proses pemahaman ataupun pemberian makna atas suatu informasi terhadap stimulus. Stimulus didapat dari proses penginderaan terhadap objek, peristiwa, atau hubungan hubungan antar gejala yang selanjutnya diproses oleh otak. Namun proses itu tidak berhenti begitu saja, melainkan stimulus tersebut diteruskan dan proses selanjutnya disebut proses persepsi. Proses tersebut mencakup proses psikologis dan hasil dari penginderaan serta proses terakhir dari kesadaran, sehingga membentuk proses berpikir yang membentuk informasi,

\footnotetext{
${ }^{10}$ Michael Adiwijaya, 8 Jurus Jitu Mengelola Bisnis Ritel Ala Indonesia, (Jakarta: PT Elex Media Komputindo, 2010), h. 43.

${ }^{11}$ Kasmir, Pemasaran Bank, (Jakarta: Kencana, 2010), h. 145. 2001), h. 76 .

${ }^{12}$ Rambat Lupiyoadi, Manajemen Pemasaran Jasa, Teori dan Praktek, (Jakarta: salemba Empat,
} 
informasi tersebut diolah dan di interpretasikan menjadi sebuah persepsi. Pengertian persepsi adalah proses dimana stimuli stimuli diseleksi, diorganisasikan dan diinterpretasikan. ${ }^{13}$

Persepsi sebagai aktivitas yang memungkinkan manusia mengendalikan rangsangan rangsangan yang sampai kepadanya melalui alat inderanya, menjadikan kemampuan itulah dimungkinkan individu mengenali lingkungan pergaulan hidupnya. $^{14}$

Persepsi merupakan salah satu aspek psikologis yang penting bagi manusia dalam merespon kehadiran berbagai aspek dan gejala di sekitarnya. Persepsi merupakan suatu proses pemahaman ataupun pemberian makna atas suatu informasi terhadap stimulus. Stimulus didapat dari proses penginderaan terhadap objek, peristiwa, atau hubungan hubungan antar gejala yang selanjutnya diproses oleh otak. Namun proses itu tidak berhenti begitu saja, melainkan stimulus tersebut diteruskan dan proses selanjutnya disebut proses persepsi. Proses tersebut mencakup proses psikologis dan hasil dari penginderaan serta proses terakhir dari kesadaran, sehingga membentuk proses berpikir yang membentuk informasi, informasi tersebut diolah dan di interpretasikan menjadi sebuah persepsi. Pengertian persepsi adalah proses dimana stimuli stimuli diseleksi, diorganisasikan dan diinterpretasikan. ${ }^{15}$

Persepsi sebagai aktivitas yang memungkinkan manusia mengendalikan rangsangan rangsangan yang sampai kepadanya melalui alat inderanya, menjadikan kemampuan itulah dimungkinkan individu mengenali lingkungan pergaulan hidupnya. ${ }^{16}$

\section{Pembiayaan Murābahah}

Dalam kegiatan penyaluran dana, Bank Syariah melakukan investasi dan pembiayaan. Disebut investasi karena prinsip yang digunakan adalah prinsip penanaman dana atau penyertaan dan keuntungan yang diperoleh bergantung pada

\footnotetext{
${ }^{13}$ Philip Kottler, Manajemen Pemasaran, Edisi Ketigabelas, h.179.

${ }^{14}$ Nugroho J Setiadi, Prilaku Konsumen: Konsep dan Implikasi untuk Strategi dan Penelitian, Pemasaran (Jakarta: Prenada Media Group, 2013), h.91.

${ }^{15}$ Philip Kottler, Manajemen Pemasaran, Edisi Ketigabelas, h.179.

${ }^{16}$ Nugroho J Setiadi, Prilaku Konsumen: Konsep dan Implikasi untuk Strategi dan Penelitian, Pemasaran (Jakarta: Prenada Media Group, 2013), h.91.
} 
kinerja usaha yang menjadi objek penyertaan tersebut sesuai dengan nisbah bagi hasil yang telah diperjanjikan sebelumnya. Disebut pembiayaan karena Bank Syariah menyediakan dana guna membiayai kebutuhan nasabah yang memerlukannya dan layak memperolehnya. Keduanya disebut dengan istilah "pembiayaan". 17

Murābahah adalah jasa pembiayaan dengan mengambil bentuk transaksi jual beli dengan cicilan. M. Umar Chapra mengemukakan bahwa murābahah merupakan transaksi yang sah menurut ketentuan syariat apabila resiko transaksi tersebut menjadi tanggungjawab pemodal sampai penguasaan atas barang (possesion) telah dialihkan kepada nasabah. ${ }^{18}$

Hipotesis dapat didefinisikan sebagai jawaban sementara yang kebenarannya masih harus diuji atau rangkuman simpulan teoritis yang diperoleh dari tinjauan pustaka. Hipotesis juga merupakan proposisi yang akan diuji keberlakuannya atau merupakan suatu jawaban sementara atas pertanyaan penelitian. ${ }^{19}$ Dalam penelitian ini dapat diambil hipotesis atau jawaban sementara yaitu:

1) $\mathrm{H}_{1}$ :Ada pengaruh faktor prosedur terhadap minat nasabah dalam mengajukan pembiayaan murābahah pada BPRS Bumi Artha Sampang KC Kebumen.

2) $\mathrm{H}_{2}$ :Ada pengaruh faktor lokasi terhadap minat nasabah dalam mengajukan pembiayaan murābahah pada Bank BPRS Bumi Artha Sampang KC Kebumen.

3) $\mathrm{H}_{3}$ :Ada pengaruh faktor persepsi terhadap minat nasabah dalam mengajukan pembiayaan murābahah pada BPRS Bumi Artha Sampang KC Kebumen.

4) $\mathrm{H}_{4}$ :Ada pengaruh secara simultan antara faktor prosedur, lokasi dan persepsi pada Bank Syariah terhadap minat nasabah dalam mengajukan pembiayaan murābahah pada BPRS Bumi Artha Sampang KC Kebumen.

\footnotetext{
${ }^{17}$ Zainul Arifin, Dasar-Dasar Manajemen Bank Syariah, (Jakarta: Pustaka Alvabet, 2005), h. 185.

${ }^{18}$ Sutan Remy Syahdeini, Perbankan Islam, (Jakarta: PT Pustaka Utama Grafiti, 2007), h. 65.

${ }^{19}$ Nanang Martono, Metode Penelitian Kuantitatif, (Jakarta: PT Raja Grafindo, 2014), h. 67.
} 


\section{METODE PENELITIAN}

Dalam penelitian ini digunakan jenis penelitian kuantitatif dengan pendekatan deskriptif. Penelitian kuantitatif adalah penelitian yang berlandaskan pada filsafat positivisme, digunakan untuk meneliti pada populasi atau sampel tertentu, teknik pengambilan sampel pada umumnya dilakukan secara random, pengumpulan data menggunakan instrumen penelitian, analisis data bersifat kuantitatif/statistik dengan tujuan untuk menguji hipotesis yang telah ditetapkan. ${ }^{20}$

Sedangkan metode deskriptif dapat diartikan sebagai prosedur pemecahan masalah yang diselidiki dengan menggambarkan atau melukiskan keadaan subjek atau objek penelitian (seseorang, lembaga, masyarakat dan lain-lain) pada saat sekarang berdasarkan fakta fakta yang tampak atau sebagaimana adanya. ${ }^{21}$

Dari tema pembahasan, penelitian ini tergolong jenis penelitian lapangan yang bersifat deskriptif kuantitatif yaitu penelitian yang dilakuakan untuk mengumpulkan data dan untuk menguji atau menjawab pertanyaan mengenai status terakhir suatu objek yang diteliti. ${ }^{22}$

Sumber data yang penulis gunakan dalam penelitian ini yaitu data primer dan data sekunder. Sumber data primer yang penulis gunakan dalam penelitian ini adalah data yang diperoleh melalui kuisioner kepada nasabah pembiayaan murābahah pada BPRS Bumi Artha Sampang KC Kebumen dan data sekunder dalam penelitian ini diperoleh dari hasil wawancara, dokumentasi, jurnal, internet dan publikasi yang diperoleh dari BPRS Bumi Artha Sampang KC Kebumen. Populasi penelitian ini meliputi seluruh nasabah BPRS Bumi Artha Sampang KC Kebumen yaitu berjumlah 879 nasabah. Dalam penelitian ini teknik sampling yang digunakan yaitu nonprobability sampling dengan teknik purposive sampling. Purposive sampling adalah teknik pengambilan sampel dengan pertimbangan tertentu yang di pilih dengan cermat sehingga relevan dengan rancangan

\footnotetext{
${ }^{20}$ Lexy J Moleong, Metode Penelitian Kualitatif, (Bandung: PT. Remaja Rosdakarya, 2006), h. 6.

${ }^{21}$ Soejono. Metode Penelitian Suatu Pemikiran dan Penerapan, (Jakarta: Pustaka LP3ES Indonesia, 1999), h. 23.

${ }^{22}$ Muhamad, Metodologi Penelitian Ekonomi IslamPendekatan Kuantitatif, (Jakarta: Rajawali Pers, 2008), h. 18 .
} 
penelitian. ${ }^{23}$ Teknik pengumpulan data adalah hal yang paling vital dalam suatu penelitian, oleh karena itu ada beberapa teknik yang digunakan dalam pengumpulan data. Cara peneliti dalam memperoleh data yang diperlukan terkait judul penelitian Yaitu, Metode kuesioner (angket), Wawancara, dan Dokumentasi.

Teknik Analisis Data

1. Uji Validitas

2. Uji Reliabilitas

3. Uji Asumsi Klasik
a. Uji Normalitas
b. Uji Multikolinieritas
c. Uji Heteroskedatisitas
d. Uji Autokorelasi

4. Uji Hipotesis
a. Uji Regresi Berganda
$\mathrm{Y}=\mathrm{a}+\mathrm{b}_{1} \mathrm{X}_{1}+\mathrm{b}_{2} \mathrm{X}_{2}+\mathrm{b}_{3} \mathrm{X}_{3}+\mathrm{b} \mathrm{X}_{4}+\mathrm{b}_{5} \mathrm{X}_{5}+\mathrm{e}$
b. Uji t
c. Uji F
d. Uji Koefisien Determinasi $\left(\mathrm{R}^{2}\right)$

\section{ANALISIS DAN PEMBAHASAN}

Bedirinya PT. BPR Syariah Bumi Artha Sampang dirintis sejak awal tahun 2005 yang diprakarsai oleh keinginan Bapak H. Kholipan yang merupakan pengusaha asli Sampang. Pria kelahiran Cilacap, 05 Februari 1967 ini berkeinginan untuk mendirikan BPR. Kemudian Bapak Buyar Winarso yang merupakan seorang pengusaha asal Kebumen memperkenalkan Bapak Kholipan dengan saudaranya yang mantan pegawai Bank, yaitu Bapak Soedjito. Kemudian terjadilah komunikasi yang intens antara keduanya. ${ }^{24}$

PT. BPR Syariah Bumi Artha Sampang didirikan berdasarkan Akta Pendirian No. 6 Tanggal 6 September 2006, dibuat dihadapan Naimah, SH MH notaries di

\footnotetext{
${ }^{23}$ Muhammad, Metodologi Penelitian Ekonomi Islam Pendekatana Kuantitatif, ( Jakarta: PT Raja Grafindo, 2008), h. 175

${ }^{24}$ Brosur Sejarah BPRS Bumi Artha Sampang KC Kebumen, 2020.
} 
Cilacap, dan telah mendapatkan pengesahan dari Departemen Hukum dan HAM No. W9.00204 HT:01.01 Tahun 2006 Tanggal 12 Desember 2006, dan berdasarkan Surat Keputusan Bank Indonesia No. 9/24/Kep-GBI uni 2007 tentang pemberian ijin usaha. ${ }^{25}$

PT. BPR Syaraiah Bumi Artha Sampang saat ini sudaH cukup berkembang dengan adanya 4 kantor kas yaitu Kantor Kas Sidareja, Kantor Kas Cipari, Kantor Kas Cimanggu dan Kantor Kas Cilacap, serta memiliki 3 kantor cabang yaitu Kantor Cabang Sidareja, Kantor Cabang Kebumen dan Kantor Cabang Purwokerto. Pendirian BPRS Bumi Artha Sampang KC Kebumen didirikan pada tahun 2007. ${ }^{26}$

1. Uji Validitas

\begin{tabular}{|c|c|c|c|}
\hline \multirow{2}{*}{ Pernyataan } & $\begin{array}{c}\text { Hasil Uji Validitas Variabel Prosedur }\left(\mathrm{X}_{1}\right) \\
\text { Corrected item-total } \\
\left.\text { correlation ( } \mathrm{r}_{\text {hitung }}\right)\end{array}$ & $\mathrm{r}_{\text {tabel }}$ & Keterangan \\
\hline No 1 & 0,402 & 0,209 & Valid \\
\hline No 2 & 0,634 & 0,209 & Valid \\
\hline No 3 & 0,780 & 0,209 & Valid \\
\hline NO 4 & 0,713 & 0,209 & Valid \\
\hline NO 5 & 0,855 & 0,209 & Valid \\
\hline No 6 & 0,697 & 0,209 & Valid \\
\hline No 7 & 0,746 & 0,209 & Valid \\
\hline
\end{tabular}

Sumber : Data Sekunder, 2020

Dapat dilihat pada tabel 4.4 Di atas bahwa pernyataan nomor 1,2,3,4,5,6,7 memiliki $r_{\text {hitung }}>r_{\text {tabel }}$. Maka dapat disimpulkan bahwa pernyataan nomor 1,2,3,4,5,6,7 adalah valid dan layak untuk digunakan sebagai pernyataan dalam kuesioner penelitian.

Hasil Uji Validitas Variabel Kualitas lokasi $\left(\mathrm{X}_{2}\right)$

$$
\begin{aligned}
& { }^{25} \text { Ibid., } \\
& { }^{26} \text { Ibid., }
\end{aligned}
$$




\begin{tabular}{|c|c|c|c|}
\hline Pernyataan & $\begin{array}{c}\text { Corrected item-total } \\
\text { correlation }\left(\mathrm{r}_{\text {hitung }}\right)\end{array}$ & $\mathrm{r}_{\text {tabel }}$ & Keterangan \\
\hline No 1 & 0,342 & 0,209 & Valid \\
\hline No 2 & 0,694 & 0,209 & Valid \\
\hline No 3 & 0,733 & 0,209 & Valid \\
\hline No 4 & 0,720 & 0,209 & Valid \\
\hline No 5 & 0,760 & 0,209 & Valid \\
\hline No 6 & 0,822 & 0,209 & Valid \\
\hline No 7 & 0,817 & 0,209 & Valid \\
\hline
\end{tabular}

Sumber: Data Primer, 2020

Dari hasil tabel 4.5 menunjukkan bahwa nomor 1,2,3,4,5,6 dan 7 memiliki $r_{\text {hitung }}>r_{\text {tabel. }}$ Maka dapat disimpulkan bahwa pernyataan nomor 1,2,3,4,5,6 dan 7 adalah valid dan layak untuk digunakan sebagai pernyataan dalam kuisioner penelitian.

\begin{tabular}{|c|c|c|c|}
\multicolumn{2}{c|}{ Hasil Uji Validitas Variabel Kualitas Prosedur $\left(\mathrm{X}_{3}\right)$} \\
\hline \multirow{2}{*}{ Pernyataan } & $\begin{array}{c}\text { Corrected item-total } \\
\left.\text { correlation ( } \mathrm{r}_{\text {hitung }}\right)\end{array}$ & $\mathrm{r}_{\text {tabel }}$ & Keterangan \\
\hline No 1 & 0,580 & 0,209 & Valid \\
\hline No 2 & 0,577 & 0,209 & Valid \\
\hline No 3 & 0,834 & 0,209 & Valid \\
\hline No 4 & 0,655 & 0,209 & Valid \\
\hline No 5 & 0,767 & 0,209 & Valid \\
\hline No 6 & 0,726 & 0,209 & Valid \\
\hline No 7 & 0,751 & 0,209 & Valid \\
\hline
\end{tabular}


Sumber: Data Primer, 2020

Dapat dilihat pada tabel 4.6 di atas menunjukkan bahwa pernyataan nomor 1 2,3,4,5,6,7 memiliki $r_{\text {hitung }}>r_{\text {tabel }}$. Maka dapat disimpulkan bahwa pernyataan nomor 1,2,3,4,5,6 dan 7 adalah valid dan layak untuk digunakan sebagai pernyataan dalam kuisioner penelitian.

\begin{tabular}{|c|c|c|c|}
\hline \multicolumn{2}{|c|}{ Hasil Uji Validitas Variabel Loyalitas Nasabah (Y) } \\
\hline Pernyataan & $\begin{array}{c}\text { Corrected item-total } \\
\text { correlation }\left(\mathrm{r}_{\text {hitung }}\right)\end{array}$ & $\mathrm{r}_{\text {tabel }}$ & Keterangan \\
\hline No 1 & 0,386 & 0,209 & Valid \\
\hline No 2 & 0,335 & 0,209 & Valid \\
\hline No 3 & 0,365 & 0,209 & Valid \\
\hline No 4 & 0,810 & 0,209 & Valid \\
\hline No 5 & 0,816 & 0,209 & Valid \\
\hline No 6 & 0,869 & 0,209 & Valid \\
\hline No 7 & 0,844 & 0,209 & Valid \\
\hline No 8 & 0,934 & 0,209 & Valid \\
\hline
\end{tabular}

Sumber: Data Primer, 2020

Dapat dilihat pada tabel 4.7 di atas menunjukkan bahwa pernyataan nomor 1,2,3,4,5,6,7 dan 8 memiliki $r_{\text {hitung }}>r_{\text {tabel. }}$. Maka dapat disimpulkan bahwa pernyataan nomor 1,2,3,4,5,6,7 dan 8 adalah valid dan layak untuk digunakan sebagai pernyataan dalam kuisioner penelitian.

\section{Uji Reliabilitas}

Uji Reliabilitas dapat dilakukan secara bersama-sama terhadap seluruh butir atau item pertanyaan dalam kuisioner penelitian. Jika nilai Cronbach's Alpha $>r$ tabel maka kuisioner dinyatakan reliabel. Sementara jika nilai Cronbach's Alpha < r tabel maka kuisioner dinyatakan tidak reliabel. ${ }^{27}$ Untuk menguji Reliabilitas

\footnotetext{
${ }^{27}$ www.spssindonesia.com, diakses pada hari Senin, 28 Desember 2020, pukul 03.30
} 
menggunakan SPSS Versi 25. Adapun hasil pengujian Reliabilitas dapat dilihat pada tabel dibawah ini:

\begin{tabular}{|c|c|c|c|}
\hline & Hasil Uji Reliabilitas & \\
\hline Variabel & 0,209 & 0,829 & Reliabel \\
\hline Prosedur $\left(\mathrm{X}_{1}\right)$ & 0,209 & 0,835 & Reliabel \\
\hline Lokasi $\left(\mathrm{X}_{2}\right)$ & 0,209 & 0,849 & Reliabel \\
\hline Persepsi $\left(\mathrm{X}_{3}\right)$ & 0,209 & 0,872 & Reliabel \\
\hline Minat Nasabah $(\mathrm{Y})$ & & Klphan \\
\hline
\end{tabular}

Sumber: Data Primer, 2020

Dari tabel 4.8 Pengolahan uji reliabilitas di atas diketahui bahwa variabel X1, $\mathrm{X}_{2}, \mathrm{X}_{3}$ dan $\mathrm{Y}$ memiliki nilai Cronbach's Alpha $>\mathrm{r}$ tabel. Sehingga dapat disimpulkan bahwa variabel $\mathrm{X}_{1}, \mathrm{X}_{2}, \mathrm{X}_{3}$ dan $\mathrm{Y}$ adalah reliabel.

3. Uji Asumsi Klasik

a. Uji Normalitas

\section{Hasil Uji Normalitas}

Kolmogorov-Smirnov One Sample Kolmogorov Smirnov Test

One-Sample Kolmogorov-Smirnov Test

Unstandardized

Residual

\section{$\mathrm{N}$}

Normal

Mean

Parameters $^{\mathrm{a}, \mathrm{b}}$

Std. Deviation

Absolute

Positive

Negative

Most Extreme

Negative

Test Statistic

Asymp. Sig. (2-tailed)

88
.0000000
1.63100947
.074
.070
-.074
.074
$.200^{\mathrm{c}, \mathrm{d}}$

a. Test distribution is Normal.

b. Calculated from data.

c. Lilliefors Significance Correction.

$\mathrm{d}$. This is a lower bound of the true significance.

Sumber : Data Primer, 2020 
Berdasarkan tabel 4.9 One-Sample Kolmogorov-Smirnov Test diperoleh angka Asymp. Sig. (2-tailed) 0,000 >0,05. Dengan demikian diketahui bahwa data penelitian berdistribusi normal.

b. Uji Multikolinieritas

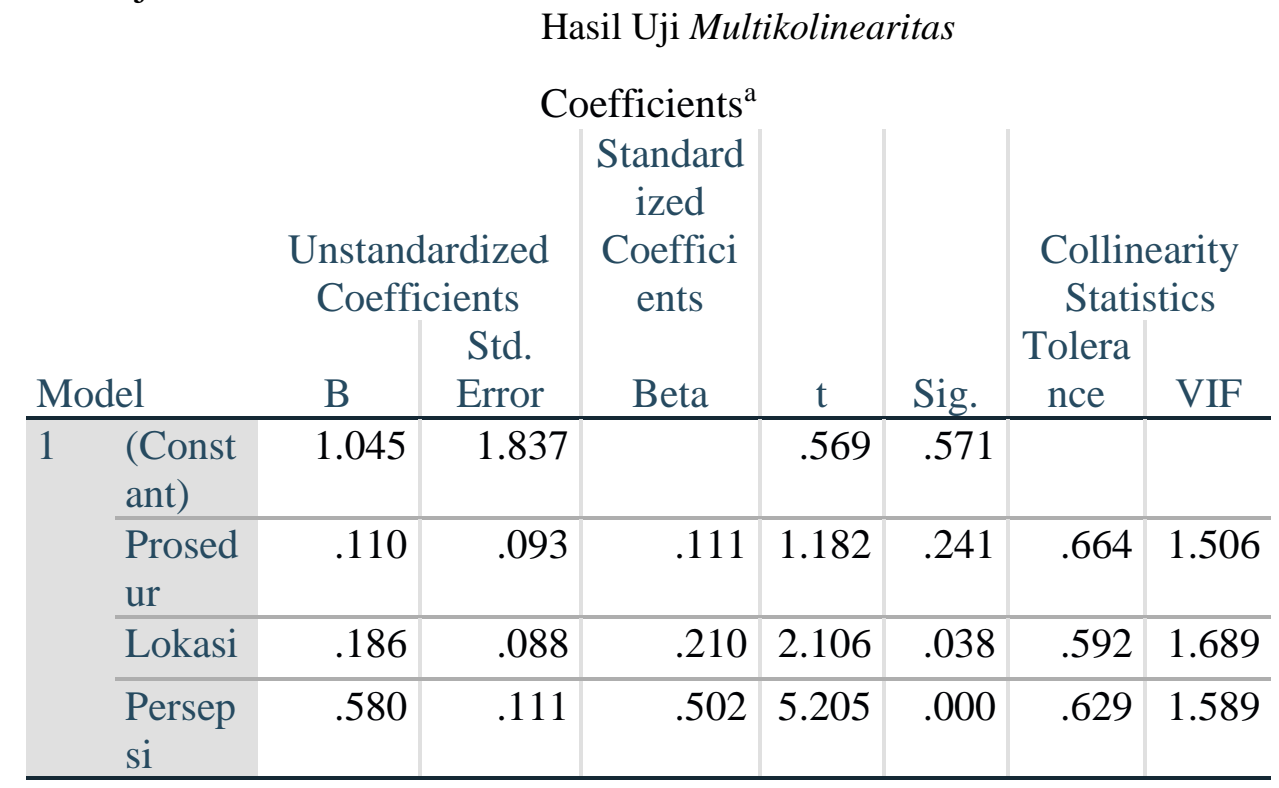

a.) Dependent Variable: Minat

Dari tabel 4.9 di atas terlihat bahwa nilai VIF variabel Prosedur sebesar 1,506, variabel Lokasi sebesar 1,689 dan variabel Persepsi sebesar 1,589. Nilai VIF dari ketiga variabel tersebut kurang dari 10,00 dan nilai tolerance dari variabel kedua tersebut lebih besar dari 0,10 maka artinya tidak terjadi multikolinieritas dalam model regresi. 


\section{c. Uji Heteroskedatisitas}

Hasil Uji Heteroskedastisitas

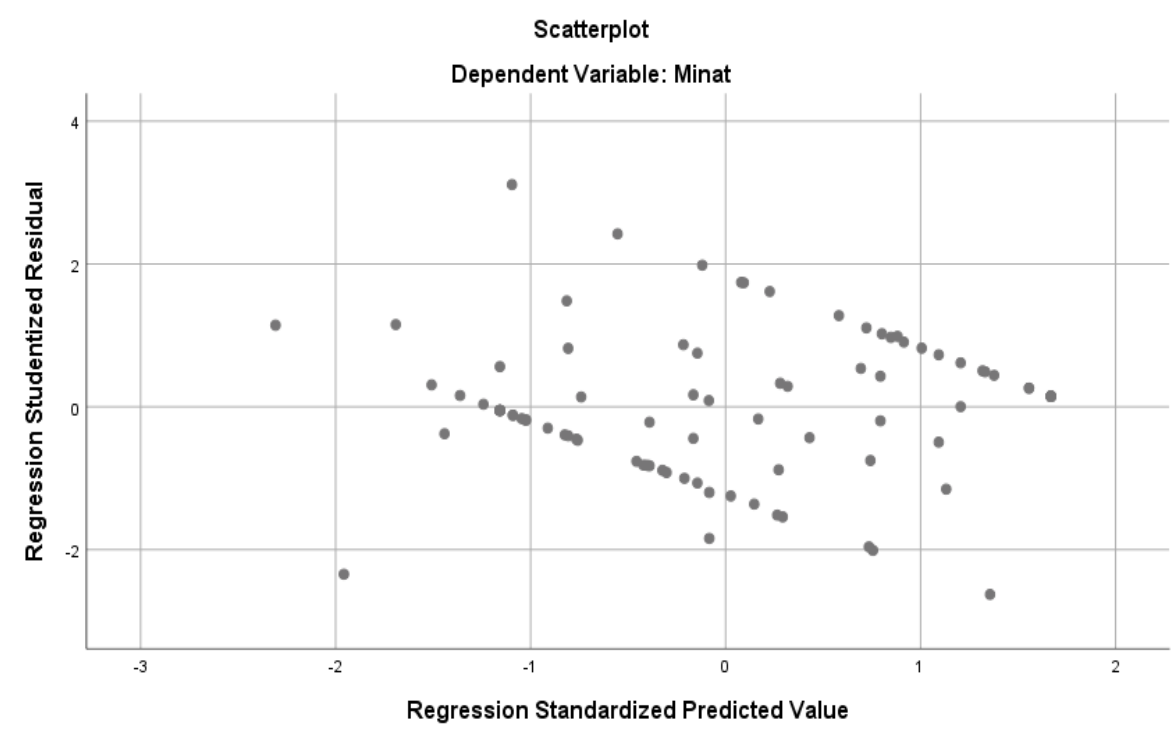

Data Primer, 2020

Dari gambar 4.31di atas terlihat titik-titik menyebar secara acak di atas dan di bawah atau di sekitar angka 0, titik-titik tidak mengumpul hanya di atas dan di bawah saja, dan titik-titik tidak membentuk pola tertentu yang teratur. Maka dapat disimpulkan bahwa tidak terjadi heteroskedastisitas dalam penelitian ini.

d. Uji Autokorelasi

Hasil Uji Autokorelasi

\begin{tabular}{|c|c|c|c|c|c|}
\hline \multicolumn{6}{|c|}{ Model Summary } \\
\hline Model & $\mathrm{R}$ & $\begin{array}{c}\mathrm{R} \\
\text { Square }\end{array}$ & $\begin{array}{l}\text { Adjusted } \\
\text { R Square }\end{array}$ & $\begin{array}{l}\text { Std. Error of } \\
\text { the Estimate }\end{array}$ & $\begin{array}{l}\text { Durbin- } \\
\text { Watson }\end{array}$ \\
\hline 1 & $.061^{\mathrm{a}}$ & .004 & -.017 & 1.444 & 2.463 \\
\hline
\end{tabular}

a). Predictors: (Constant), Persepsi, Lokasi, Prosedur

B). Dependent Variable: Minat

Sumber: Data Primer, 2020.

Berdasarkan tabel 4.10 output "Model Summary" di atas, diketahui nilai DurbinWatson (d) adalah sebesar 2,463. Selanjutnya nilai ini akan kita bandingkan dengan nilai tabel durbin watson pada signifikan $5 \%$ dengan rumus $(\mathrm{k} ; \mathrm{N})$. adapun jumlah variabel independen adalah 3 atau " $\mathrm{k} "=3$, sementara jumlah sampel atau " $\mathrm{N} "=88$, maka $(\mathrm{k} ; \mathrm{N})=(3 ; 88)$. Angka ini kemudian kita lihat pada distribusi nilai tabel durbin watson. Maka 
ditemukan nilai dL sebesar 1,583 dan dU sebesar 1,772. Nilai Durbin Watson (d) sebesar 2,463 lebih besar dari batas atas (dU) yakni 1,724 Maka sebagaimana dasar pengambilan keputusan dalam uji durbin watson di atas, dapat disimpulkan bahwa tidak terdapat masalah atau gejala autokorelasi.

4. Uji Hipotesis

a. Uji Regresi Berganda

s Hasil Uji Regresi Berganda Variabel Prosedur (X1)

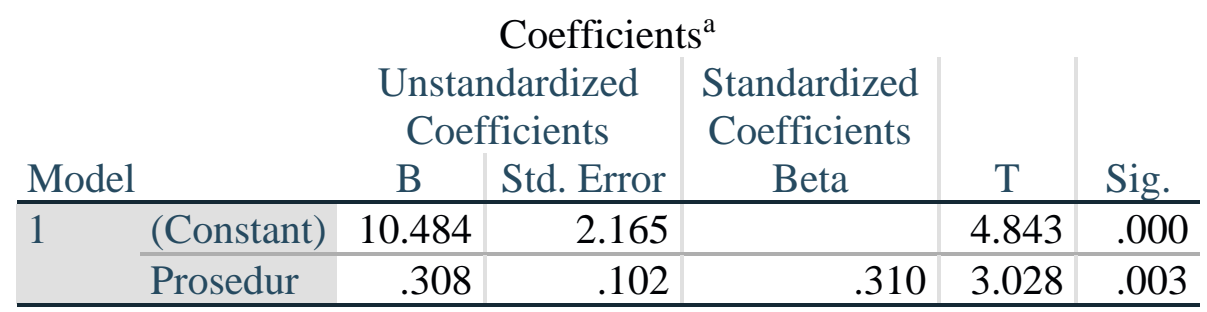

a). Dependent Variable: Minat

Sumber : Data primer, 2020

Hasil Uji Regresi Berganda Variabel Prosedur (X2)

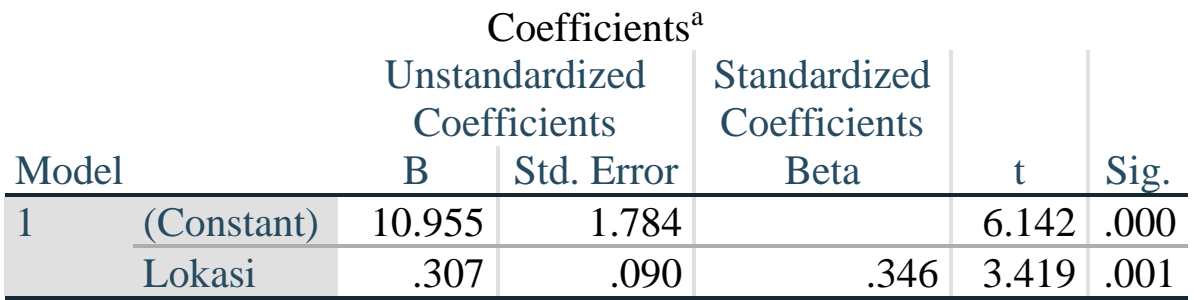

a). Dependent Variable: Minat

Sumber : Data primer, 2020

Hasil Uji Regresi Berganda Variabel Prosedur (X3)

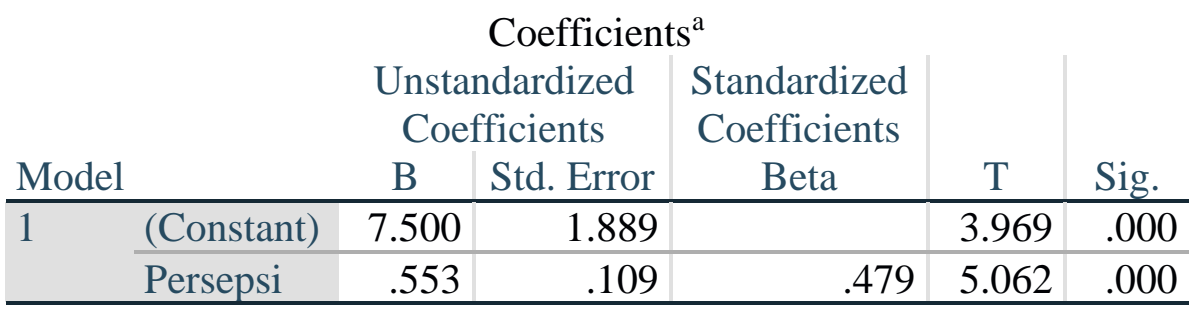

a). Dependent Variable: Minat

Sumber : Data primer, 2020

Dapat dilihat pada tabel 4.11,4.12 dan 4.13 di atas yaitu variabel bebas X1 = 3,028, $X_{2}=3,419$ dan $X_{3}=5,062$ dengan persamaan regresi yakni $Y=a+b_{1} X_{1}+$ $b_{2} X_{2}+b_{3} X_{3}+e$

Keterangan : 
$\mathrm{Y}=$ Variabel terikat (Minat Nasabah Melakukan Pembiayaan Murābahah Pada BPRS Bumi Artha Sampang KC Kebumen )

a $\quad=$ Bilangan Konstanta

$\mathrm{X} 1=$ Variabel Prosedur

$\mathrm{X} 2=$ Variabel Lokasi

$\mathrm{X} 3=$ Variabel Persepsi

e $\quad=$ Standart error

$\mathrm{b}_{1} \& \mathrm{~b}_{2}=$ koefisien regresi masing-masing variabel independent.

b. Uji t

Diketahui tabel 4.11, 4.12 dan 4.13 bahwa t tabel untuk $\mathrm{df}=88$ $2=86$ dengan signifikasi $5 \%$ adalah 1,987 . Untuk mengetahui apakah hipotesa yang diajukan signifikan atau tidak maka perlu membandingkan antara $t_{\text {hitung }}$ dengan $t_{\text {tabel }}$. Jika nilai $t_{\text {hitung }}>t_{\text {tabel }}$ maka hipotesa diterima, Sebaliknya jika nilai $t_{\text {hitung }}<\mathrm{t}_{\text {tabel }}$ maka hipotesa tidak dapat diterima. Dari tabel di atas bahwasanya thitung model Prosedur lebih besar dari tabel yaitu 3,028 yang berarti hipotesa diterima, untuk thitung model Lokasi lebih besar dari t tabel yaitu 3,419 yang berarti hipotesa diterima dan untuk $t_{\text {hitung }}$ model Persepsi lebih besar dari tabel yaitu 5,062 dan juga dengan nilai signifikan $<0,05$ yang berarti hipotesa diterima.

c. Uji F

Tabel 4.15 Hasil Uji F

ANOVA $^{\mathrm{a}}$

\begin{tabular}{|c|c|c|c|c|c|c|}
\hline \multicolumn{7}{|c|}{ ANOVA $^{\mathrm{a}}$} \\
\hline \multicolumn{2}{|c|}{ Model } & $\begin{array}{l}\text { Sum of } \\
\text { Squares }\end{array}$ & Df & $\begin{array}{l}\text { Mean } \\
\text { Square }\end{array}$ & $\mathrm{F}$ & Sig. \\
\hline \multirow[t]{3}{*}{1} & $\begin{array}{l}\text { Regressio } \\
n\end{array}$ & 238.563 & 3 & 79.521 & 28.862 & $.000^{\mathrm{b}}$ \\
\hline & Residual & 231.437 & 84 & 2.755 & & \\
\hline & Total & 470.000 & 87 & & & \\
\hline
\end{tabular}

a. Dependent Variable: Minat

b. Predictors: (Constant), Persepsi, Prosedur, Lokasi

Sumber : Data Primer, 2020

Dari tabel 4.14 di atas hasil perhitungan statistik menunjukkan nilai $F_{\text {hitung }}$ lebih besar dari $F_{\text {tabel }}=28,862$ lebib besar dari 3,10. Hal ini berarti bahwa secara simultan Prosedur, Lokasi \& Persepsi berpengaruh 
terhadap minat nasabah. Selain bisa ditentukan dengan perbandingan nilai F Hitung dengan F tabel, bisa juga berdasarkan Nilai Signifikansi (Sig) dengan ketentuan apabila nilai Sig lebih rendah dari 0,05 maka hipotesis diterima atau dengan kata lain variabel $\mathrm{X}$ berpengaruh simultan terhadap variabel Y, berdasarkan tabel output SPSS di atas di ketahui nilai Sig sebesar 0,000. karena nilai Sig 0,000 lebih besar dari 0,05 maka sesuai dengan dasar pengambilan keputusan dalam uji $\mathrm{F}$ dapat di simpulkan bahwa hipotesis diterima atau dengan kata lain variabel $\mathrm{X}$ berpengaruh simultan terhadap variabel $\mathrm{Y}$.

d. Uji Koefisien Determinasi $\left(\mathrm{R}^{2}\right)$ Hasil Uji Koefisien Determinasi $\left(\mathrm{R}^{2}\right)$

Model Summary ${ }^{\mathrm{b}}$

\begin{tabular}{|c|c|c|c|c|}
\hline Model & $\mathrm{R}$ & R Square & $\begin{array}{l}\text { Adjusted R } \\
\text { Square }\end{array}$ & $\begin{array}{c}\text { Std. Error of the } \\
\text { Estimate }\end{array}$ \\
\hline 1 & $.712^{\mathrm{a}}$ & .508 & .490 & 1.660 \\
\hline
\end{tabular}

a. Predictors: (Constant), Persepsi, Prosedur, Lokasi

b. Dependent Variable: Minat

Sumber: Data Primer, 2020

Dari tabel 4.15 di atas dapat dilihat bahwa besar pengaruh variabel independen $\left(\mathrm{X}_{1}, \mathrm{X}_{2} \& \mathrm{X}_{3}\right)$ secara simultan terhadap variabel dependen (Y) sebesar 0,490 atau $49 \%$. Sisanya $51 \%$ dipengaruhi oleh variabel selain Prosedur, Lokasi dan Persepsi yang tidak diteliti dalam penelitian ini.

\section{KESIMPULAN}

Berdasarkan penelitian dan hasil pengolahan data dengan menggunakan regresi linear berganda dengan jumlah responden 88 yang diperoleh dari kuisioner nasabah BPRS Bumi Artha Sampang KC Kebumen, maka dapat ditarik kesimpulan sebagai berikut:

1. Prosedur bank secara parsial berpengaruh signifikan terhadap minat nasabah dalam melakukan pembiayaan murābahah pada BPRS Bumi Artha Sampang KC 
Kebumen. Hasil ini berdasarkan pengujian dengan SPSS versi 25 diperoleh untuk variabel $X_{1}$ dengan nilai $t_{\text {hitung }} 3,028$ lebih besar dari $t_{\text {tabel }} 1,987$. Dengan demikian, maka hipotesis pertama diterima.

2. Lokasi BPRS Bumi Artha KC Kebumen secara parsial berpengaruh signifikan terhadap minat nasabah dalam melakukan pembiayaan murābahah pada BPRS Bumi Arta Sampang KC Kebumen.Hasil ini berdasarkan pengujian dengan SPSS diperoleh untuk variabel $\mathrm{X}_{2}$ diperoleh nilai $\mathrm{t}_{\text {hitung }}$ 3,419 lebih besar dari $\mathrm{t}_{\text {tabel }}$ 1,987. Dengan demikian, maka hipotesis kedua diterima.

3. Persepsi masyarakat tentang bank syariah secara parsial berpengaruh signifikan terhadap minat nasabah dalam melakukan pembiayaan murābahah pada BPRS Bumi Artha Sampang KC Kebumen. Hasil ini berdasarkan pengujian dengan SPSS untuk variabel $\mathrm{X}_{3}$ diperoleh nilai thitung 5,062 lebih besar dari $t_{\text {tabel }} 1,987$ dengan signifikansi 0,908. Dengan demikian, maka hipotesis kedua diterima.

4. Prosedur bank, Lokasi bank dan Persepsi nasabah secara simultan berpengaruh terhadap minat nasabah dalam melakukan pembiayaan murābahah pada BPRS Bumi Artha Sampang KC Kebumen. Hal ini berdasarkan hasil perhitungan statistik menunjukkan nilai $F_{\text {hitung }} 28,862$ lebih besar dari $F_{\text {tabel }} 3,10$. Hal ini berarti bahwa hipotesis diterima atau dengan kata lain variabel $\mathrm{X}$ berpengaruh simultan terhadap variabel Y. Dengan nilai koefisien determinasi sebesar 0,490 atau $49 \%$ dan sisanya $51 \%$ dipengaruhi oleh faktor lain yang tidak diteliti dalam penelitian ini

\section{DAFTAR PUSTAKA}

Adiwijaya, Michael. 2010. 8 Jurus Jitu Mengelola Bisnis Ritel Ala Indonesia. Jakarta: PT Elex Media Komputindo.

Ahmadi, Abu. 1998. Psikologi Umum. Jakarta: Rieneka Cipta.

Antonio, Karnaen A. Permana dan Muhammad Syafi'i,1999. Apa dan Bagaimana Bank Islam. Solo: Amanah Bunda Sejahtera, cet. Ke-3.

Antonio, M. Syafi'i. 2001. Bank Syariah:Dari Teori Ke Praktik. Jakarta: Gema Insani.

Arifin, Zainul. 2005. Dasar-Dasar Manajemen Bank Syariah. Jakarta: Pustaka Alvabet. 
Baridwan, Zaki. 1992. Sistem Akuntansi, Penyusunan Prosedur dan Metode. Yogyakarta. BPFE.

Brosur Sejarah BPRS Bumi Artha Sampang KC Kebumen. 2020.

Kasmir. 2006. Marketing dan Kasus Kasus Pilihan. Jakarta: Center For Academic Publishing Service.

Kasmir. 2010. Pemasaran Bank. Jakarta: Kencana.

Kottler, Philip. 2008. Manajemen Pemasaran. Jakarta: Erlangga. Edisi Ketiga belas.

Lupiyoadi, Rambat. 2001. Manajemen Pemasaran Jasa, Teori dan Praktek. Jakarta: salemba Empat.

Muhajir, Fathudin, Hary Listyadi. (2021). Penyelesaian Pembiayaan Murābahah Bermasalah Di BMT Mikat Al-Khidmah Purworejo. Al-Mubin; Islamic Scientific Journal. 10-23.

Muhajir, Dina Hady Chaeruddin. (2021). Implementasi Akad Pembiayaan Mudharabah di BMT An-Nawawi Cabang Pituruh Perspektif Hukum Ekonomi Syariah. At-Tasyri'iy Jurnal Prodi Perbankan Syariah. 1-17.

Muhamad. 2008. Metodologi Penelitian Ekonomi IslamPendekatan Kuantitatif. Jakarta: Rajawali Pers.

Setiadi, Nugroho J. 2013. Prilaku Konsumen: Konsep dan Implikasi untuk Strategi dan Penelitian Pemasaran. Jakarta: Prenada Media Group.

Soejono. 1999. Metode Penelitian Suatu Pemikiran dan Penerapan. Jakarta: Pustaka LP3ES Indonesia.

Syahdeini, Sutan Remy. 2007. Perbankan Islam. Jakarta:PT Pustaka Utama Grafiti.

Umar, Husein. 2003. Metode Riset Bisnis. Jakarta: PT. Gramedia Pustaka Utama. www.spssindonesia.com 